\title{
AUTONOMOUS SOLAR ELECTRIC GENERATING STATIONS FOR PRIVATE FARMS IN NORTH-WEST RUSSIA
}

\author{
Evgenii Timofeev, Andrey Erk, Anna Efimova \\ Federal Scientific Agroengineering Centre VIM, Russia \\ timofeev_ev84@mail.ru,4666866@bk.ru
}

\begin{abstract}
Currently, renewable energy sources occupy a significant place in the energy sector of agriculture under climatic conditions of the North-West of the Russian Federation. Solar energy has the greatest application potential among them. The study purpose was to determine the efficiency of a solar power plant in the North-West region. The study tested a designed and manufactured experimental autonomous solar electric generating station, which consisted of three hetero-structural photovoltaic modules with a capacity of $315 \mathrm{~W}$ each (Hevel Energy Group, Russia), a storage battery, an inverter, and a charge controller. The study used the "passive experiment" method and statistical data analysis. The results were obtained for the natural operation conditions, under different solar radiation intensity (irradiance) and ambient air temperature. The solar electric generating station demonstrated $22 \%$ efficiency and the on-peak energy generation of $1920 \mathrm{Wh}$. The combined small-size (up to $50-70 \mathrm{~kW}$ ) electrical stations were found most promising for electricity supply of the facilities in the remote private farms pig houses for 10 to 30 head, houses for rabbits, poultry, sheep, and goats, as well as residential houses.
\end{abstract}

Keywords: solar energy, photovoltaic module, load customer, efficiency, farm, studies.

\section{Introduction}

Solar energy has the greatest application potential among renewable energy sources. The literature review revealed that the solar energy was practicable to be harvested even under climatic conditions of the North-West of the Russian Federation $[1 ; 2]$.

Traditionally, it is believed that the optimal use of solar energy in this zone is in summer for air heating in hay, grain and seeds drying, and for technical and drinking water heating in livestock farms [3-6]. To generate electricity from solar energy was once considered economically unprofitable [7]. However, this is done in the countries with the same climatic conditions, including private farms [8-10]. Moreover, the recent market offers a wide variety of photovoltaic equipment with constantly decreasing prices $[2 ; 10]$. The combined small-size (up to $50-70 \mathrm{~kW}$ ) electrical stations were found most promising for electricity supply of the facilities in the remote private farms - pig houses for 10 to 30 head, houses for rabbits, poultry, sheep, and goats [11-13], as well as residential houses [14].

The purpose of the study was to determine the application efficiency of a solar electric generating station in the North-West region. The study objective was to identify the optimal parameters and operation modes of photovoltaic modules within the station (their best efficiency).

\section{Materials and methods}

The photovoltaic modules were tested at the Institute for Engineering and Environmental Problems in Agricultural Production (IEEP) - branch of Federal Scientific Agroengineering Centre VIM in real operating conditions. The voltage and current strength in the modules were measured to identify their variation under solar radiation exposure on cloudy and sunny days.

The study was conducted from June to October 2020 as the passive experiment (observation).

The study object was a solar electric generating station with three HVL-315/HJT hetero-structural photovoltaic modules (Hevel Energy Group, Russia), MultiPlus 24/1200/25 inverter, Smart Solar controller and a storage battery (Fig. 1).

An $800 \mathrm{~W}$ oil radiator was installed as a load customer.

The south-oriented photovoltaic models were installed on a wooden deck at a height of $10.5 \mathrm{~m}$ with a tilt angle of $67^{\circ}$.

The following parameters were measured when testing the solar electric generating station:

- $\quad$ solar irradiance $S, \mathrm{~W} \cdot \mathrm{m}^{-2}$;

- voltage on a photovoltaic module $U_{P V-m o d}, \mathrm{~V}$;

- voltage at the consumer end (load) $U_{\text {load }}, \mathrm{V}$;

- electric current in the circuit "photovoltaic module - consumer (load)" $I_{(P V-m o d-l o a d)}, \mathrm{A}$; 
Humidity, wind speed and direction, atmospheric pressure and ambient air temperature were neglected due to their extremely insignificant effect on the parameters of the solar electric generating station.

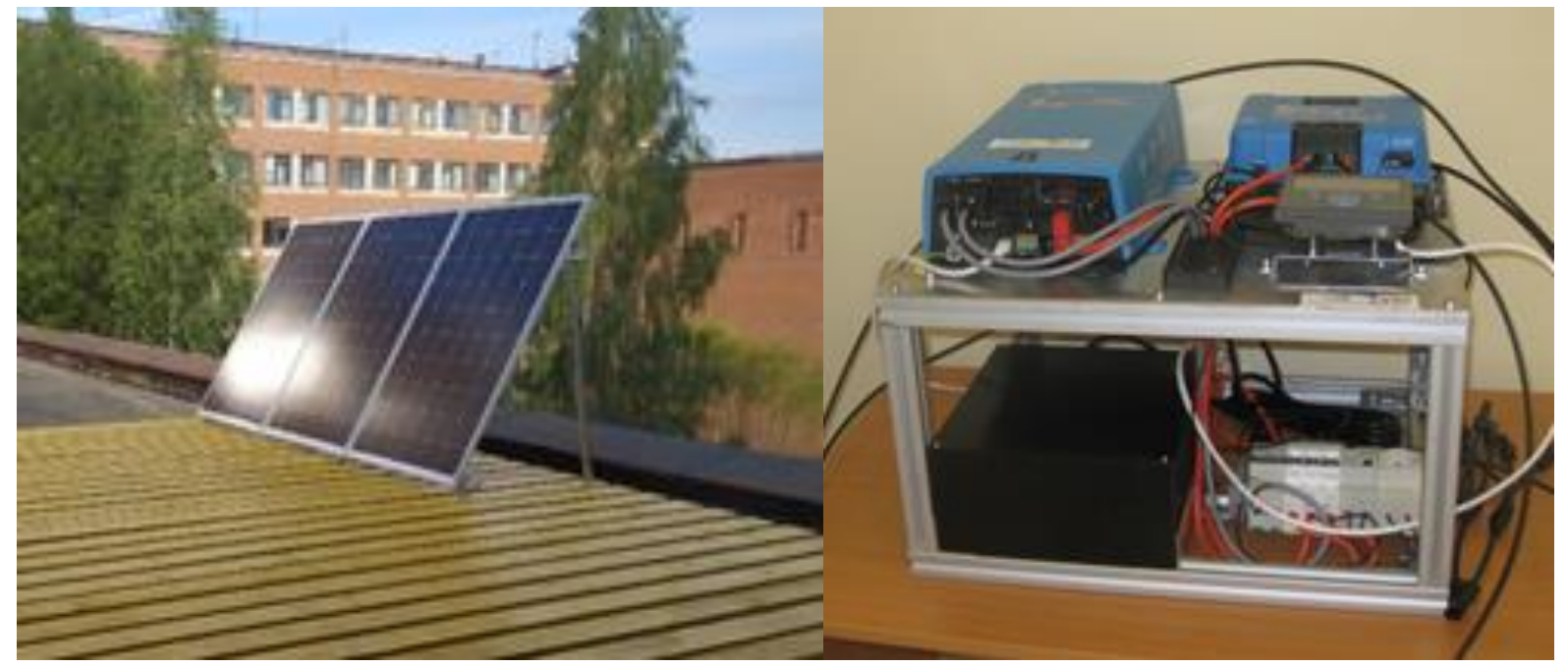

Fig. 1. Experimental solar electric generating station

Energy conversion in a PV module is based on the photovoltaic effect that occurs in heterogeneous semiconductor structures exposed to solar radiation. Consequently, the difference in electric potentials is created at the module's terminals. If there is a load customer, the electric current flow starts.

The solar irradiance was measured by the TES-1333R solar power meter. The voltage and electric current values in all electrical circuit elements were measured by the Color Control GX Retail controller with display. Voltage sensors were installed on PV modules' terminals and on the contact elements to consumers. Electric current sensors were included directly into the electrical circuit at "PV module load" elements. Table 1 shows a complete list of equipment and instruments used in the study.

Table 1

\section{List of equipment and instruments}

\begin{tabular}{|l|l|l|}
\hline \multicolumn{1}{|c|}{ Title } & \multicolumn{1}{c|}{ Trademark } & \multicolumn{1}{c|}{ Measurement accuracy } \\
\hline Measurement of solar irradiance & TES-1333R & - \\
\hline $\begin{array}{l}\text { Measurement of electrical } \\
\text { parameters }\end{array}$ & Color Control GX Retail & $\begin{array}{l} \pm 1.0 \% \text { (voltage) } \\
\pm 0.8 \% \text { (electric current) }\end{array}$ \\
\hline Photovoltaic module & HVL-315/HJT & - \\
\hline Storage battery & $24 \mathrm{~V}, 78$ Ah & - \\
\hline Oil radiator (load) & $800 \mathrm{~W}$ capacity & - \\
\hline
\end{tabular}

The following main factors were recorded every 30 minutes during daylight hours under the natural solar radiation: solar irradiance $S$, voltage $U_{P V-\text { mod }}$ and current $I_{(P V-\text { mod -load })}$ in the circuit "PV module consumer (load)". The efficiency of a PV module was determined as the ratio of the maximum power output to the solar irradiance:

$$
\eta=\frac{I_{\text {(PY.mod-load })} \cdot U_{P Y \text { mod }}}{S} \times 100 \%
$$

Color Control GX Retail continuously received the information from voltage and electric current sensors and archived it in electronic form with a time reference.

Electronic archiving of processes allowed plotting the graphs of the time-related variation in the parameters under study.

The study results were analysed on PC in MS Excel software, with correlation and regression analysis being the method applied. The maximum efficiency of the photovoltaic module was determined depending on real external factors. 


\section{Results and discussion}

The experiment resulted in the dependences of the efficiency of PV modules on variable external conditions:

$$
\eta=f\left(I_{(P V \text { mod-load })}, U_{P V \text { mod }}, S\right)
$$

The variation graphs of the power output of PV-modules and solar irradiance, as well as variation graphs of the current strength and voltage of PV-modules during the daylight hours were plotted to analyse the data obtained (Fig. 2 and Fig. 3).

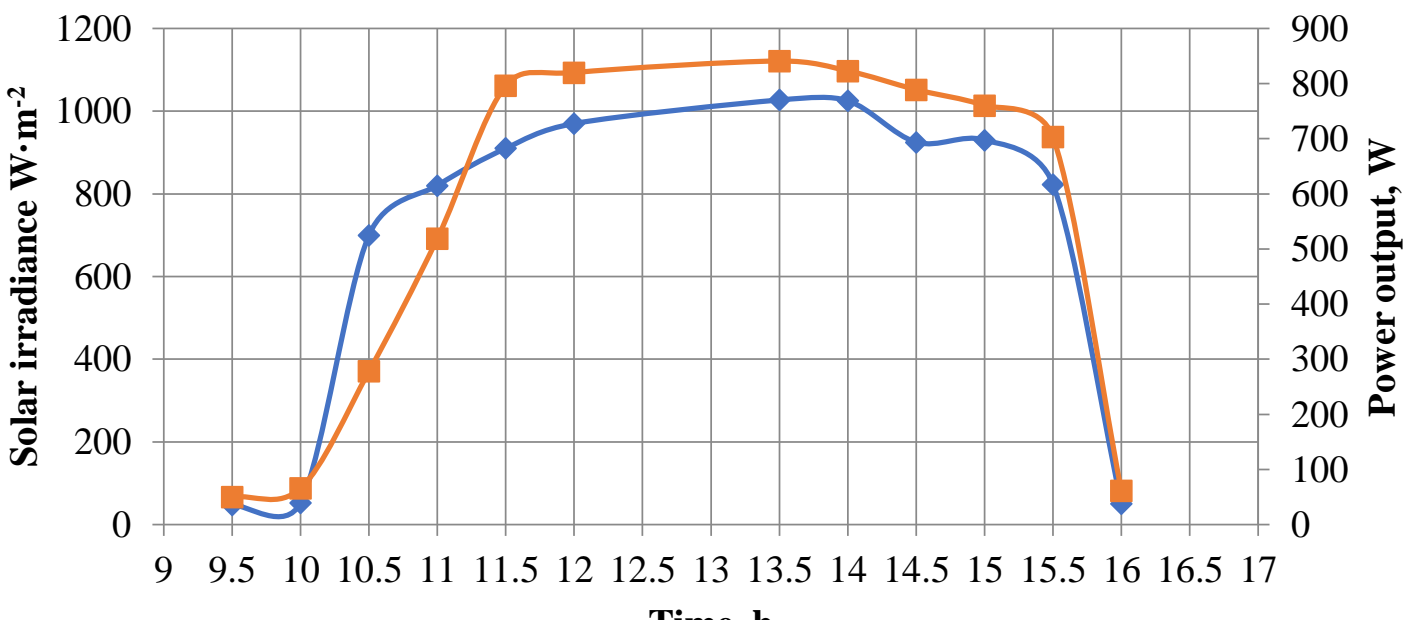

Time, h

$\multimap$ Solar irradiance, $\mathrm{W} \cdot \mathrm{m}^{-2} \quad \longrightarrow$ Power output, $\mathrm{W}$

Fig. 2. Variation pattern of power output of PV-modules and solar irradiance

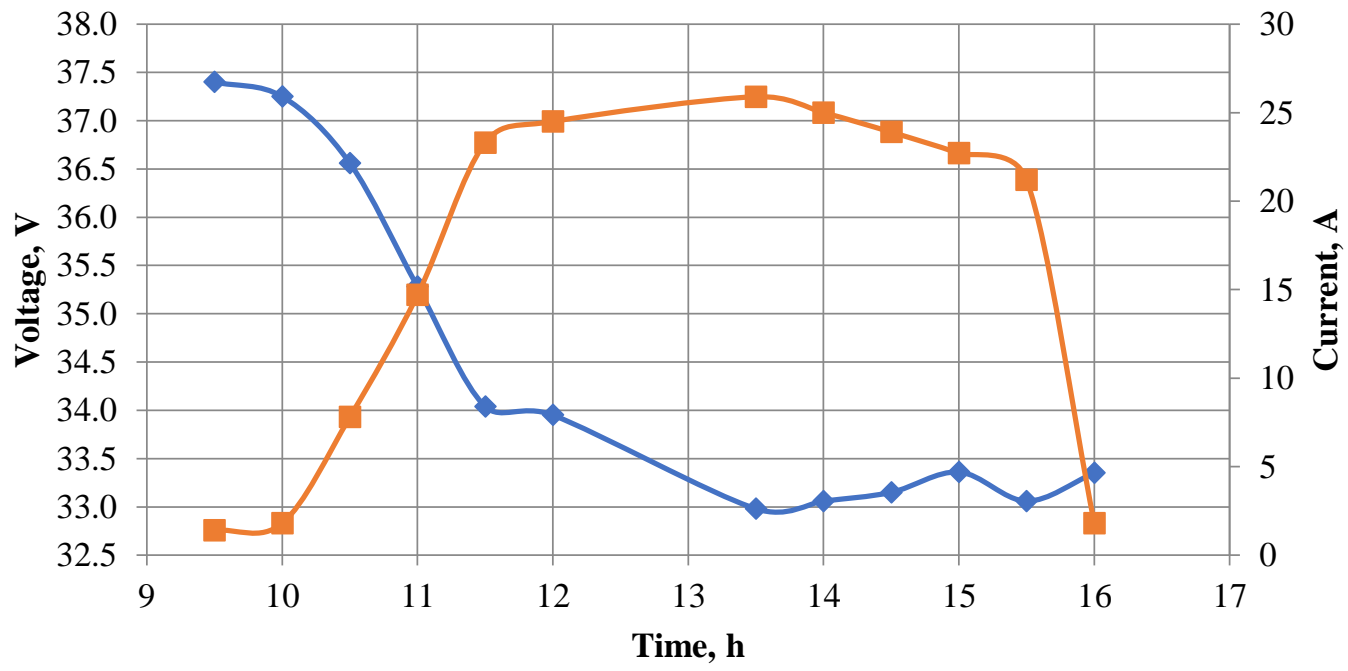

$\leadsto$ Voltage, $\mathrm{V} \rightarrow$ Current, $\mathrm{A}$

Fig. 3. Variation pattern of the current strength and voltage of PV-modules

The plotted graphs in Fig. 2 show a direct dependence of power output on solar irradiance, which characterises the normal operation of a solar electric generating station. At the same time, the variation graphs of current and voltage of PV-modules in Fig. 3 shows the operation mode, when the rated power output of the module is determined at a voltage in the range of 30-40 V and a current in the range of 15$25 \mathrm{~A}$. 
A regression analysis of the data obtained was performed in MS Excel to reveal the dependence of solar irradiance and module efficiency with a reliability level of $95 \%$.

The variation pattern of efficiency depending on solar irradiance is shown in Figure 4.

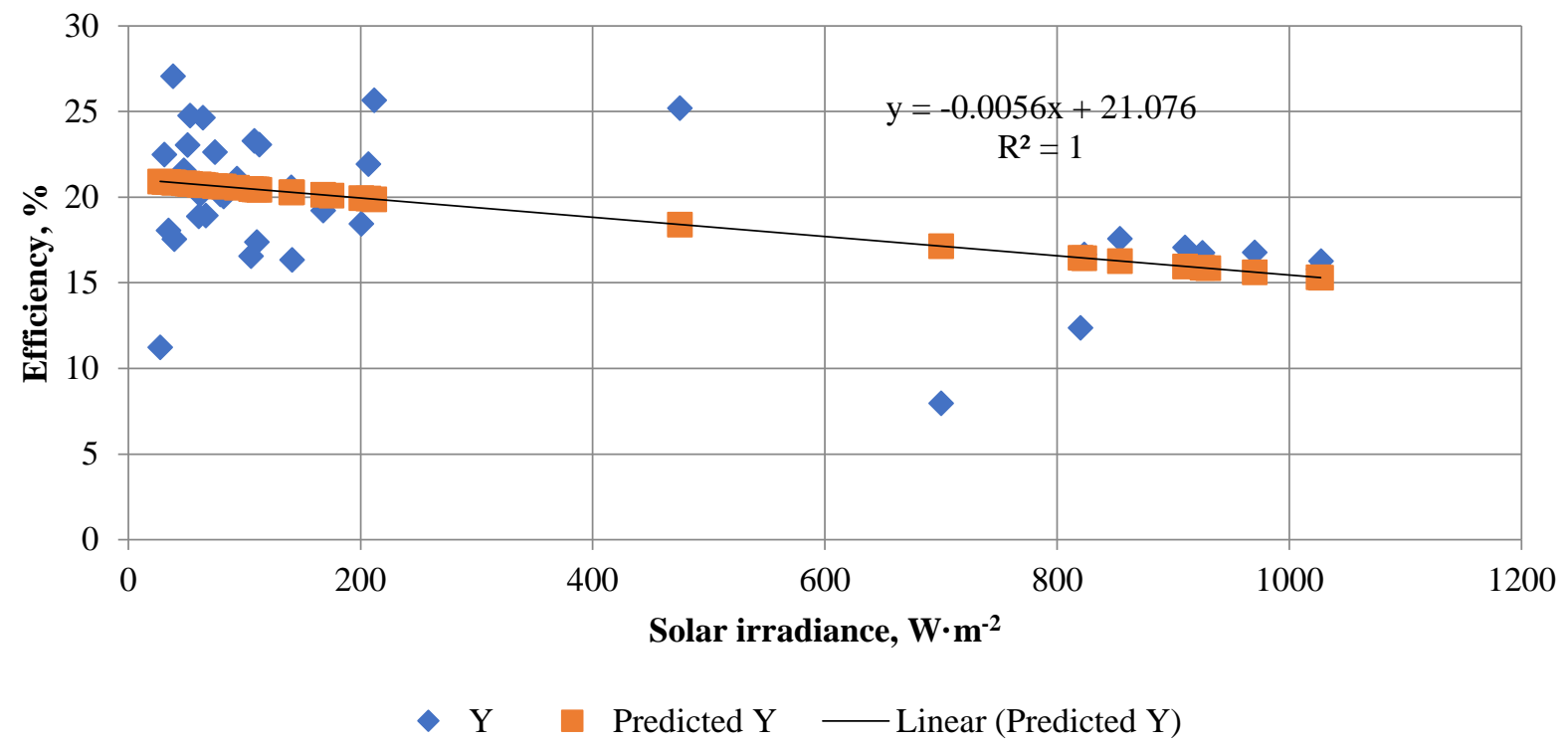

Fig. 4. Dependence of efficiency on solar irradiance of PV-modules

The highest efficiency of the tested modules was obtained at low values of solar irradiance up to $200 \mathrm{~W} \cdot \mathrm{m}^{-2}$; under such conditions the efficiency reached $27 \%$. At higher values of solar irradiance, the efficiency decreased to $18-19 \%$. This is explained by the fact that part of energy is converted to heat. The average value according to the analysis was $21.07 \%$. The daily energy generation by the station was $1920 \mathrm{~W}$.

Based on the obtained power output values, the efficiency of PV-modules was determined as the ratio of the maximum power output to the solar irradiance. The study has shown that the efficiency of the tested modules was at the level of $22 \%$ for the conditions of the North-West of the Russian Federation, which practically coincided with their passport specifications of $23 \%$. Today, the average efficiency of high-quality solar panels ranges from 17 to $21 \%$ [16]. One of the ways to improve the effectiveness of solar electric generation stations is to use them together with other energy sources [17].

\section{Conclusions}

The study has shown that the efficiency of the tested modules was at the level of $22 \%$ for the conditions of North-West Russia. The highest efficiency of the tested modules of $27 \%$ was obtained at low values of solar irradiance up to $200 \mathrm{~W} \cdot \mathrm{m}^{-2}$. At higher values of solar irradiance, the efficiency decreased to $18-19 \%$. The rated power output of the module was determined at a voltage in the range of $30-40 \mathrm{~V}$ and a current in the range of 15-25 A. The data on the electrical energy accumulation received during the study period prove the applicability of solar electric generating stations as an alternative energy source in North-West Russia.

\section{Acknowledgement}

A part of this work was performed within the framework of KS1675 project "Russian-Finnish Bioeconomy Competence Centre - BioCom" of the "South-East Finland - Russia Cross-Border Cooperation (CBC) Programme 2014-2020".

\section{References}

[1] Jordan D. C., Kurtz S. R. Photovoltaic degradation rates - an analytical review. Progress in photovoltaics: Research and Applications. 2013. Vol. 21 No. 1, pp. 12-29. DOI: 10.1002/pip.1182 
[2] Global Market Outlook. For Solar Power/2018 - 2022. SolarPower Europe. [online][01.03.2021]. Available at: https://www.solarpowereurope.org/wp-content/uploads/2018/09/Global-MarketOutlook-2018-2022.pdf

[3] Bazilian M., Onyeji I., Liebreich M., MacGill I., Chase J., Shah J., Gielen D., Arent D, Landfear D., Zhengrong S. Re-considering the economics of photovoltaic power. Renewable Energy. 2013, vol. 53, issue C, pp. 329-338, DOI: 10.1016/j.renene.2012.11.029

[4] Tsanova T. Renewables produce $85 \%$ of global power, nearly $50 \%$ of energy in 2050 . Renewables Now. 2017. [online][01.03.2021] Available at: https://renewablesnow.com/news/renewablesproduce-85-of-global-power-nearly-50-of-energy-in-2050-582235/

[5] Díaz P. et al. Field analysis of solar PV-based collective systems for rural electrification. Energy. 201, vol. 36 (5), pp. 2509-2516. DOI: 10.1016/j.energy.2011.01.043

[6] Rahman K. et al. Comparative study of stand-alone and hybrid solar energy systems suitable for off-grid rural electrification: A review. Renewable and Sustainable Energy Reviews. 2013, vol. 27, pp.738-752. DOI: 10.1016/j.rser.2013.06.043.

[7] Jano A., Tohoda S., Matsuyama K. et al. 24.7 record efficiency hit solar sell on thin silicon wafer. Proceedings of the 28th European Photovoltaic Solar Energy Conference and Exhibition, 30 September - 4 October, 2013, Paris, France, pp. 1846-1848.

[8] Richter A., Benick J., Feldmann F., Fell A., Hermle M., Glunz S.W. n-Type Si solar cells with passivating electron contact: Identifying sources for efficiency limitations by wafer thickness and resistivity variation. Solar Energy Materials and Solar Cells. 2017. Vol. 173. pp. 96-105

[9] Sachenko A.V., Kostylyov V.P., Vlasiuk V.M., Sokolovskyi I.O., Evstigneev M. The influence of the excitation nonradiative recombination in silicon on the photoconversion efficiency. Proc. of the $32^{\text {nd }}$ Eur. Photovoltaic Solar Energy Conf. and Exhibition. Munich, Germany, 2016. p. 141

[10] Kaushika N.D. et al. Solar Photovoltaics. Technology, System Design, Reliability and Viability, 1st edition. Springer. 2018, 178 p.

[11] Ros T.G. Rhodium complexes and particles on carbon nanofibres: surface chemistry of carbon nanofibres and catalytic properties of supported rhodium species. Proefschriftterverkr-ging van de graad van doctor aan de Universiteit Utrecht, Utrecht, 2002

[12] Steward D., Doris E., Krasko V., Hillman D. The effectiveness of state-level policies on solar market development in different state contexts. [online] [01.03.2021] Available at: http://www.nrel.gov/docs/fy14osti/61029.pdf

[13] Wirth H., Schneider K. Recent facts about photovoltaics in Germany. Fraunhofer ISE. 2018. [online][01.03.2021] Available at:

https://www.ise.fraunhofer.de/content/dam/ise/en/documents/publications/studies/recent-factsabout-photovoltaics-in-germany.pdf

[14] Cheng Z., Elham D., Behdad M. Figure of merit analysis of a hybrid solar-geothermal power plant. Engineering. 2013. No. 5. pp. 26-31

[15] Fitri Oktaviani Purwaningsih et al. Make-up wells drilling cost in financial model for a geothermal project. IOP Conference Series: Earth and Environmental Science, Volume 103, 6th ITB International Geothermal Workshop (IIGW2017) 22-23 March 2017, Bandung, Indonesia. 012010

[16] Efficiency of solar batteries. [online][16.04.2021] Available at: https://www.termicosolar.com/kpd-solnechnyh-batarej/ (In Russian)

[17] Sarker S. Feasibility analysis of a renewable hybrid energy system with producer gas generator fulfilling remote household electricity demand in Southern Norway, Renewable Energy, 2016, vol. 87, Part 1, pp. 772-781. 